$60-301$

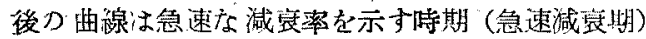
と，緩やかな減衰率をるつた（緩徐減衰期）二つの 相からなること，(2) Wever 等か云5 recovery phase 等は見られないことを知り，(3)急速隇衰期 は内耳毛細胞の*ヌボ；公么の障碍されるによる変 化であららと述べた。

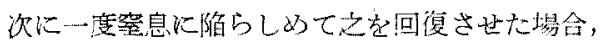

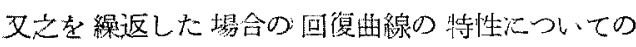

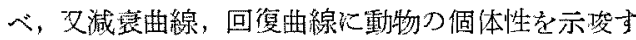
る如き傾向のあること省指摘した。

\section{7. 超微小電極による小腦つ聴性反応に} دwて (7 分)

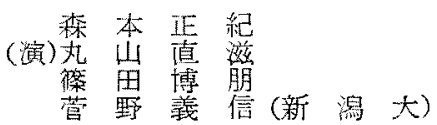

谞来小脳の㯖性反応江閤する観察は誘発要位に限 つて、た。誘発琶位によると誘導の限局性が不碳実 で立体的局在は分明しないそここで尖端口径 $0.1 \mu$

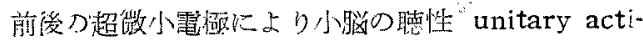
vity 党探索した。

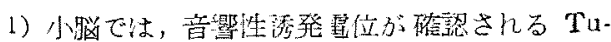
ber vermisでも，得られる unitary spike の大

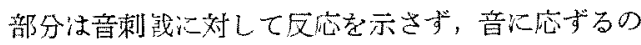

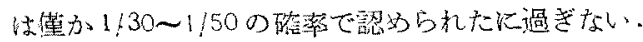
主として 1 相性又は 2 相性刀自発师電であり，封汇

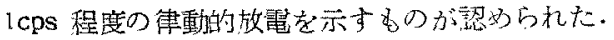

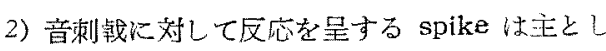
て Tuber vermis の領域で得られており，すべて 非常に閾值が高い. ( $80 \mathrm{db}$ 程度).

3）音刺铙炕対して spike の減少するすのと增加 ずるいのと2 型式がみられた。

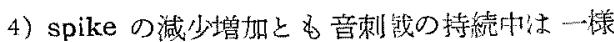
で, on 双は off effect 宗すものは現在选磪認さ れていない。

1) 項の所見より，小脳では多尰の機能領が電盟 して居るものと思われる. 又 2) 項の所見より，小 脳俚音の認知に性余り関保がなく，聴性軍動反射 の如きるのと関係して居るのではないかと推察さ れる。

$3-13$

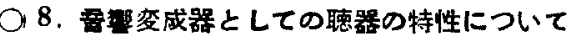

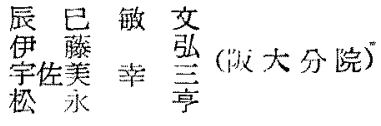

現在の㯖覚理諭は内耳が基礎膜の振動速度により

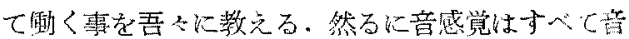
压に比例するるのとして取㧐われて来ている。この

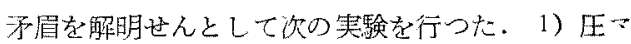

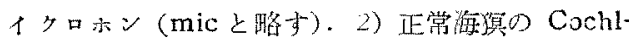

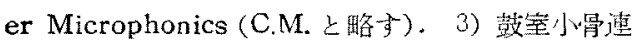

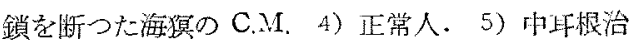
手術後の耳. 6) 迷路開空術後耳 を以て空内定常

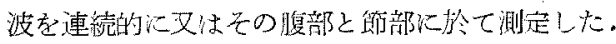

成績：压 mic，正常敏综つ C.M. 兏び正常人の

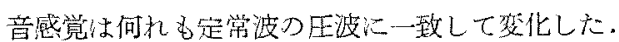

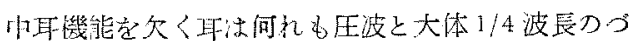
机老示し定常波の速度波汇一致するのが見られた。

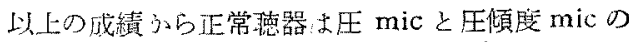

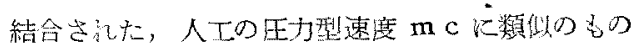

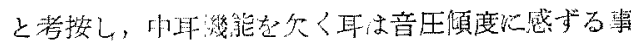

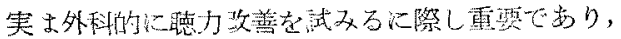
聴力改善つ一つの可能性汇就いて詇じた。

\section{○9. 㯖小筋刀発生学的研究}

$$
\text { 中本賢(広島大) }
$$

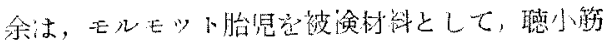
の登生学的研究を行い，次の如き相胃を得た。(1)

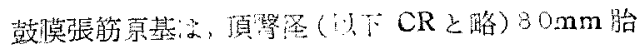

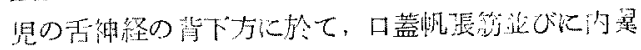

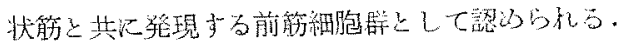

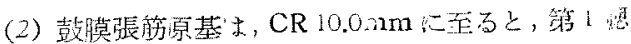

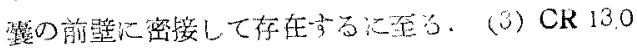

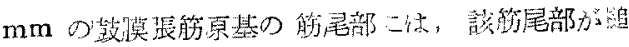

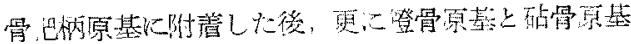

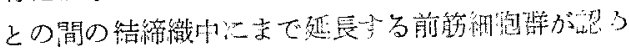

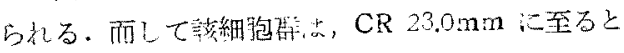

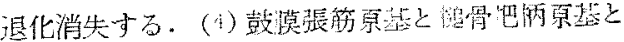

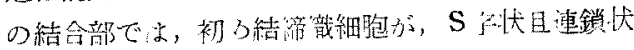
飞並列して上述炣著は結令しているが，CR $82.0 \mathrm{~mm}$

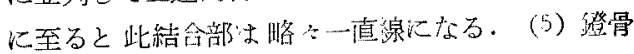

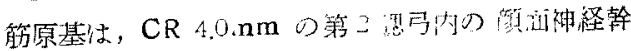

